\title{
HUBUNGAN PERSEPSI DUKUNGAN SOSIAL DAN RESILIENSI ORANG TUA ANAK BERKEBUTUHAN KHUSUS
}

\author{
Mauna* \\ Rahmadianty Gazadinda** \\ *Universitas Negeri Jakarta
}

Novaria Rahma***

DOI: https://doi.org/10.21009/JPPP.092.08

\author{
Alamat Korespondensi: \\ novarahma23@gmail.com
}

\begin{abstract}
This study aims to determine the positive relationship between perceived social support and resilience in parents of children with special needs. Resilience can be used by parents as a source of strength in the face of adversity. The instruments used in this study is were the Multidimensional Scale of Perceived Social Support (MSPSS) developed by Zimet (1988) to measure the perceived social support and Connor Davidson Resilience Scale (CDRISC) developed by Connor and Davidson (2003) for resilience variables. The sample in this study amounted to 164 parents who have children with special needs. This research uses purposive sampling technique. Method of data analysis in testing hypotheses using correlation techniques. The analysis results showed that the significance ( $p$ ) of 0,000 ( $p<0,05)$. Based on these results, it can be conclude that the hypothesis of this study has been accepted, which stated that there is was a significant relationship between the perceived social support and resilience in parents of children with special needs.
\end{abstract}

\section{Keywords}

perceived social support, resilience, parents of children with special needs.

\section{Pendahuluan}

Anak berkebutuhan khusus adalah anak yang mengalami gangguan perkembangan, kelainan, atau kecacatan secara fisik, emosi, mental, atau sosial sehingga mereka membutuhkan pelayanan pendidikan khusus sesuai dengan kondisi yang dialaminya (Sumekar, 2009). Selain itu, menurut Individual With Disabilities Education Act Amendments atau IDEA terdapat kategori anak berkebutuhan khusus yaitu tunanetra, tunarungu, tunaganda, tunadaksa, tunawicara, tunagrahita, hiperaktif (Attention Deficit Hyperactivity Disorder), kesulitan belajar khusus, anak lamban dalam belajar (slow learner), gifted dan autisme (Desiningrum, 2016). Indonesia merupakan salah satu Negara dengan jumlah anak berkebutuhan khusus yang terus meningkat.

Data dari Badan Pusat Statistik tahun 2017 menyatakan bahwa jumlah anak berkebutuhan khusus mencapai angka 1,6 juta anak. Hal serupa juga disampaikan oleh Menteri Pemberdayaan Perempuan yang menyatakan bahwa jumlah anak berkebutuhan khusus di Indonesia sebanyak 2,5\% dari jumlah penduduk di Indonesia.

Setiap individu memiliki tantangan dan kesulitan dalam menjalani hidupnya. Tantangan yang dialami individu dapat berasal dari berbagai latar belakang, seperti pekerjaan, lingkungan sosial, maupun keluarga. Tantangan 
Mauna

Rahmadianty Gazadinda

Novaria Rahma
Hubungan Persepsi Dukungan Sosial dan Resiliensi Orang Tua Anak Berkebutuhan Khusus dalam keluarga dihadapi oleh orang tua ketika merawat anaknya. Jika tantangan tersebut berlangsung terus-menerus dan menumpuk dapat memicu timbulnya stres.

Stres merupakan reaksi psikologis dan emosional sebagai respon terhadap tuntutan yang berasal dari diri sendiri atau dari luar (Kondalkar, 2009). Stres juga dapat dirasakan oleh orang tua yang memiliki anak berkebutuhan khusus. Penelitian menunjukkan bahwa orangtua dengan anak berkebutuhan khusus dapat mengalami stres yang tinggi, rasa sedih, dan perasaan marah setelah mengetahui anaknya mengalami down syndrome (Azmi, 2017). Responden mengemukakan bahwa ia takut ketika harus membayangkan masa depan yang akan dihadapi anaknya (Azmi, 2017). Sejalan dengan hasil penelitian tersebut, penelitian yang dilakukan oleh Webster, Majnemer, Platt, dan Shevell (2008) menunjukkan bahwa orang tua dengan anak berkebutuhan khusus memiliki tingkat stres yang signifikan setelah diukur menggunakan parental stress index short form.

Stres yang dirasakan oleh orang tua terjadi karena anak berkebutuhan khusus menunjukkan perilaku yang berbeda dari anak normal lainnya yang membuat orang tua harus bekerja lebih keras dalam mendidik mereka. Anak berkebutuhan khusus seringkali menunjukkan ekspresi yang tidak sesuai, seperti tersenyum saat tidak ada yang lucu, menghindari kontak mata, dan tidak bermain seperti anak normal lainnya (Putri, Pramesti, dan Hapsari, 2019). Orang tua dari anak berkebutuhan khusus seringkali mendapatkan stigma negatif dari masyarakat (Azni dan Nugraha, 2019). Selain itu, mereka sering merasa kesulitan untuk mencari informasi mengenai kondisi anaknya, dan kesulitan untuk mencari tempat terapi (Astuktik, dalam Azni dan Nugraha, 2019). Berbagai kesulitan yang dihadapi oleh orang tua dapat berdampak pada kesehatan fisik dan mental.

Hal tersebut membuat orang tua dengan anak berkebutuhan khusus membutuhkan kemampuan untuk bertahan pada situasi yang sulit. Kemampuan untuk bertahan pada situasi sulit biasa disebut dengan resiliensi. Connor dan Davidson (2003) mendefinisikan resiliensi sebagai kualitas yang dimiliki individu untuk bertahan, beradaptasi, dan berkembang ketika menghadapi keadaan yang sulit. Sejalan dengan definisi yang dikemukakan Connor dan Davidson, Grotberg (2003) mendefinisikan resiliensi sebagai kualitas individu dalam menghadapi, mengatasi, mempelajari, dan berubah melalui kesulitan hidup yang tak terhindarkan.

Resiliensi dapat digunakan oleh orang tua sebagai sumber kekuatan dalam menghadapi kesulitan. Hal ini didukung dengan hasil penelitian yang dilakukan oleh Greeff dan Nolting (2013) yaitu orang tua dengan anak berkebutuhan khusus yang memiliki resiliensi terlihat mampu menerima situasi yang dihadapi, dan orang tua tersebut juga memiliki hubungan yang baik antar anggota keluarga. Melalui resiliensi, orang tua dengan anak berkebutuhan khusus mampu melihat masalah yang dihadapi sebagai suatu hal yang positif (Muir dan Strnadova, 2014) sehingga mereka mampu menerima kondisi anaknya yang berbeda dengan anak lain (Azmi, 2017).

Salah satu faktor yang dapat memengaruhi resiliensi menurut Ahern (2006) adalah risk factor (faktor risiko) dan protective factor (faktor pendukung). Risk factor dalam resiliensi adalah faktor yang dapat memperburuk masalah yang dirasakan individu, sedangkan protective factor dalam resiliensi adalah faktor yang dapat membantu individu untuk bangkit dan bertahan pada masa sulit yang dirasakan seperti faktor individual, fakor komunitas, faktor budaya dan faktor keluarga (Rahmawati, Listiyandini, dan Rahmatika, 2019).

Dalam hal ini, komunitas dan keluarga adalah faktor-faktor yang berada di luar diri individu. Peran keluarga dan lingkungan ternyata memiliki dampak terhadap resiliensi

Jurnal Penelitian dan Pengukuran Psikologi, Vol. 9 , 2 , Oktober 2020 
Mauna

Rahmadianty Gazadinda

Novaria Rahma
Hubungan Persepsi Dukungan Sosial dan Resiliensi Orang Tua Anak Berkebutuhan Khusus individu. Ketika individu menghadapi kesulitan, lingkungan sekitarnya dapat membantu untuk menghadapi kesulitan tersebut. Dalam merawat anak berkebutuhan khusus, orang tua seringkali menghadapi kesulitan yang membuatnya membutuhkan bantuan dan dukungan dari orang lain. Dukungan tersebut disebut sebagai dukungan sosial.

Terdapat beberapa definisi dukungan sosial yang dikemukakan oleh para ahli. Uchino (2004) mendefinisikan dukungan sosial sebagai kenyamanan, penghargaan, kepedulian, dan bantuan yang tersedia untuk seseorang dari orang lain atau kelompok lain. Sejalan dengan yang dikemukakan oleh Uchino, Sarafino dan Smith (2014) mengemukakan bahwa individu dengan dukungan sosial percaya bahwa mereka dicintai, dihargai, serta merupakan bagian dari lingkungan sosialnya, seperti keluarga atau komunitas organisasi yang dapat memberikan bantuan ketika dibutuhkan. Sementara itu, Taylor (2004) menyatakan bahwa persepsi dukungan sosial lebih bermanfaat karena persepsi dukungan sosial dapat membantu seseorang untuk menenangkan dirinya dengan berpikir bahwa ada orang lain yang perduli terhadap dirinya dalam menghadapi stres.

Dukungan sosial dan persepsi dukungan sosial merupakan dua hal yang berbeda. Zimet, Dahlem, Zimet, dan Farley (1988) mengemukakan bahwa persepsi dukungan sosial adalah penilaian subjektif yang dilakukan individu atas sebuah dukungan, yang berasal dari keluarga, teman, serta orang yang dianggap penting (significant others). Sejalan dengan definisi sebelumnya, Eagle, Hybels, dan Proeschold- Bell (2019) mendefinisikan persepsi dukungan sosial sebagai dukungan yang dirasakan oleh individu dan individu percaya bahwa dukungan yang ia butuhkan akan tersedia.

Persepsi dukungan sosial dapat berdampak pada kebahagiaan dan kesejahteraan individu. Menurut Cohen \& Wills (1985) dukungan sosial yang tinggi akan berpengaruh pada kesejahteraan individu. Selain itu, individu dengan persepsi dukungan sosial yang tinggi akan jarang merasa kesepian (Kang, Park, dan Wallace, 2016). Individu yang memiliki tingkat persepsi dukungan sosial yang tinggi disebut sebagai positive psychosocial profile. Selain itu, persepsi individu terhadap dukungan sosial yang rendah dapat menimbulkan dampak yang tidak baik. Persepsi yang rendah pada dukungan sosial dapat membuat individu merasa kesepian, lalu persepsi yang rendah tersebut berdampak buruk pada kualitas hidup mereka (Kang, Park, dan Wallace, 2016). Selain itu, gejala depresi dapat meningkat tanpa adanya persepsi individu atas sebuah dukungan sosial (Dag dan Sen, 2018).

Penelitian terkait persepsi dukungan sosial dan resiliensi telah dilakukan oleh beberapa peneliti sebelumnya. Ong et al. (2018) menyatakan bahwa persepsi dukungan sosial merupakan salah satu media yang tepat untuk meningkatkan resiliensi pada para perawat orang tua sehingga beban yang dirasakan oleh perawat menjadi berkurang. Selain itu, penelitian yang dilakukan oleh Marija Pejicic, Milica Ristic, dan Vesna Andelkovic (2017) menunjukkan hasil bahwa persepsi dukungan sosial memiliki pengaruh terhadap resiliensi sebesar $14 \%$. Persepsi dukungan sosial tersebut merupakan persepsi dukungan sosial yang berasal dari teman sebaya.

Sejauh ini sudah ada penelitian yang membahas mengenai persepsi dukungan sosial dan resiliensi pada orang tua anak berkebutuhan khusus. Khan, Kamran, dan Ashraf (2017) menyatakan bahwa ibu yang memiliki anak berkebutuhan khusus cenderung memiliki tingkat resiliensi yang tinggi, namun memiliki persepsi yang tidak terlalu tinggi terhadap dukungan sosial yang ia terima dari keluarganya. Akan tetapi, hasil penelitian lain yang dilakukan oleh Karaman dan Efilti (2019) menunjukkan hasil bahwa total skor pada persepsi dukungan sosial memiliki hasil yang signifikan namun lemah terhadap resiliensi sehingga kurang dapat digunakan untuk 
Mauna

Rahmadianty Gazadinda

Novaria Rahma

memprediksi resiliensi orang tua dengan anak berkebutuhan khusus.

Perbedaan hasil penelitian tersebut diduga disebabkan karena adanya perbedaan negara sehingga terdapat perbedaan budaya dan lokasi dari populasi. Hal tersebut sejalan dengan yang dikemukakan oleh Carter, Park, dan Cragg (2015) bahwa perbedaan budaya dapat memengaruhi individu dalam mempersepsikan dan menangani anak berkebutuhan khusus. Sementara itu, belum ada penelitian yang membahas mengenai hubungan persepsi dukungan sosial dan resiliensi orang tua anak berkebutuhan khusus yang dilakukan di Indonesia. Oleh sebab itu, peneliti tertarik untuk meneliti hubungan persepsi dukungan sosial dan resiliensi orang tua dengan anak berkebutuhan khusus.

Tujuan dari penelitian ini adalah untuk mengetahui hubungan persepsi dukungan sosial dan resiliensi orang tua anak berkebutuhan khusus. Rumusan masalah dalam penelitian ini adalah "Apakah terdapat hubungan persepsi dukungan sosial dan resiliensi orang tua anak berkebutuhan khusus?". Hipotesis penelitian ini adalah terdapat hubungan yang signifikan antara persepsi dukungan sosial dan resiliensi orang tua anak berkebutuhan khusus.

\section{Metode Penelitian}

Dalam penelitian ini memilih untuk menggunakan pendekatan kuantitatif. Penelitian ini merupakan penelitian korelasional, peneliti akan melihat hubungan antara dua variabel atau lebih (Sangadji dan Sopiah, 2010). Populasi dalam penelitian ini adalah orang tua yang memiliki anak berkebutuhan khusus. Penelitian ini menggunakan teknik purposive sampling untuk menentukan sampel.

Purposive sampling adalah metode penetapan sampel berdasarkan kriteria yang telah ditentukan (Sangadji dan Sopiah, 2010). Kriteria sampel penelitian ini adalah orang tua yang memiliki anak berkebutuhan khusus.
Hubungan Persepsi Dukungan Sosial dan Resiliensi Orang Tua Anak Berkebutuhan Khusus
Teknik penggumpulan data yang digunakan dalam penelitian ini adalah kuesioner yang disajikan dalam bentuk Google form.

Pada bagian awal Google form para responden akan dihadapkan pada lembar inform consent, jika orang tua anak berkebutuhan khusus bersedia untuk mengisi kuesioner tersebut maka mereka akan dihadapkan dengan beberapa pernyataan. Kemudian peneliti menyebarkan kuesioner dengan menghubungi beberapa komunitas dan yayasan orangtua anak berkebutuhan khusus, seperti Komunitas ADHD, Disabilitas UPI, Forkasi Jakarta, Yayasan Peduli ASD, Roemah Difabel, Komunitas Difabel Bangkit, Drisana Development Center, Disabilities for world, Super special mom, Terapis Autisma, Komunitas Pandulisane, Yayasan Putra Fitri, dan Rumah Autis. Pada penelitian ini terdapat 164 responden yang bersedia mengisi kuesioner.

Peneliti melakukan proses penerjemahan (translate dan back translate) pada instrumen Connor Davidson Resilience Scale (CD- RISC). Kemudian peneliti melakukan expert judgment ke beberapa dosen Psikologi Universitas Negeri Jakarta. Peneliti juga melakukan uji coba instrumen kepada 42 orangtua anak berkebutuhan khusus. CD-RISC terdiri dari 25 pernyataan yang terdiri dari 5 pilihan jawaban yaitu (TSS) untuk Tidak Sama Sekali, (J) Jarang, (K) Kadang- kadang, (S) Sering, (HSS) Hampir Setiap Saat. Berdasarkan hasil uji coba instrumen CD-RISC diketahui bahwa tidak ada item yang gugur.

Sedangkan untuk variabel persepsi dukungan sosial peneliti menggunakan alat ukur Multidimensional Perceived Social Support (MSPSS) yang sudah melalui proses translate dan back translate dan expert judgment oleh peneliti sebelumnya yaitu Shabira Dintari (2019). MSPSS terdiri dari 12 pernyataan dan menggunakan tujuh pilihan jawaban yaitu Sangat Tidak Setuju (STS), Tidak Setuju (TS), Agak Tidak Setuju (ATS), Ragu-ragu (R), Agak

Jurnal Penelitian dan Pengukuran Psikologi, Vol. 9, 2, Oktober 2020 
Mauna

Rahmadianty Gazadinda

Novaria Rahma
Hubungan Persepsi Dukungan Sosial dan Resiliensi Orang Tua Anak Berkebutuhan Khusus
Setuju (AS), Setuju (S), Sangat Setuju (SS). Setelah dilakukan uji validitas dan reliabilitas diketahui bahwa tidak ada item yang gugur. Pengujian korelasi pada penelitian ini menggunakan teknik korelasi pearson product moment. Uji korelasi digunakan untuk menguji hubungan antar variabel psikologis (Rangkuti, 2017).

\section{Hasil Penelitian dan Diskusi}

Sebelum instrumen dapat digunakan, peneliti melakukan proses validitas dan reliabilitas terhadap instrumen yang digunakan. Instrumen Connor Davidson Resilience Scale (CD-RISC) memiliki reliabilitas sebesar 0,896. Selanjutnya untuk instrumen Multidimensional Perceived Social Support (MSPSS) memiliki reliabilitas sebesar 0,893 .

Peneliti melakukan pengolahan data menggunakan aplikasi SPSS untuk variabel resiliensi diperoleh nilai minimum sebesar 25 , nilai maksimum sebesar 96 , nilai rata-rata atau mean sebesar 69,65 sementara nilai median sebesar 69, dan nilai standar deviasi sebesar 11,219 .

Kemudian untuk variabel persepsi dukungan sosial diperoleh nilai minimum sebesar 27 nilai maksimum sebesar 84 , nilai rata-rata atau mean sebesar 66,84 sementara nilai median sebesar 69, dan nilai standar deviasi sebesar 11,600.

Dalam pengambilan data, peneliti berhasil mengumpulkan sebanyak 164 orang tua yang memiliki anak berkebutuhan khusus. Penelitian ini terdiri dari responden wanita berjumlah 145 orang $(88,4 \%)$ dan responden pria yang berjumlah 19 (11,6\%). Kemudian berdasarkan status pernikahan diketahui sebanyak 147 responden $(89,6 \%)$ dalam penelitian ini berstatus menikah, sementara 11 responden $(6,7 \%)$ berstatus bercerai, dan 6 responden $(3,7 \%)$ berstatus cerai mati.

Mayoritas responden yang berada dalam status menikah memiliki persepsi dukungan sosial yang tinggi. Hal ini sejalan dengan penelitian yang dilakukan oleh Azmi (2017), orang tua yang memiliki anak down syndrome menunjukkan bahwa orang tua dapat kembali optimis dan menerima keadaan anaknya setelah mendapatkan dukungan dan motivasi yang diberikan oleh keluarga. Selain itu, penelitian yang dilakukan oleh Edyta \& Damayanti (2016) menunjukkan bahwa setelah mendapatkan dukungan dari suami, ibu dari anak berkebutuhan khusus dapat kembali bersemangat dan memiliki keingan untuk bangkit bagi kepentingan anaknya. Diduga hal tersebut dapat terjadi karena orang tua anak berkebutuhan khusus yang menikah memiliki pasangan untuk berbagi cerita mengenai kesulitan yang terjadi dalam hidupnya. Responden pada penelitian yang dilakukan Azmi (2017), dan Edyta \& Damayanti (2016) adalah wanita, dan hasil penelitian menunjukkan bahwa responden memiliki persepsi yang baik atas dukungan yang berasal dari suami dan keluarga.

Data demografis berdasarkan penghasilan diketahui bahwa 115 responden $(70,1 \%)$ memiliki penghasilan 0-5 juta, 26 responden $(15,9 \%)$ memiliki penghasilan 6-10 juta, 13 responden $(7,9 \%)$ berpenghasilan 11-15 juta, 5 responden (3\%) berpenghasilan 16-20 juta, dan 5 responden (3\%) berpenghasilan lebih dari 20 juta.

Data demografis berdasarkan keikutsertaan dalam komunitas diketahui bahwa mayoritas responden dalam penelitian ini tergabung dalam komunitas orang tua anak berkebutuhan khusus yaitu sebanyak 118 responden (72\%), lalu sebanyak 46 responden (28\%) tidak tergabung dalam komunitas orang tua anak berkebutuhan khusus. Selanjutnya berdasarkan diagnosa anak dalam penelitian ini mayoritas anak terdiagnosa autisme, yaitu sebanyak 62 anak $(37,8 \%), 21$ anak (12,8\%) terdiagnosa ADHD, 21 anak $(12,8 \%)$ didiagnosa tunarungu, 15 anak $(9,1 \%)$ tunadaksa, 11 anak $(6,7 \%)$ didiagnosa kesulitan belajar khusus, 11 anak $(6,7 \%)$ tunagrahita, 11 anak $(6,7 \%)$ memiliki diagnosa yang termasuk dalam kategori lain-

Jurnal Penelitian dan Pengukuran Psikologi, Vol. 9 , 2 , Oktober 2020 
Mauna

Rahmadianty Gazadinda

Novaria Rahma

lain, 4 anak $(2,4 \%)$ tunanetra, 4 anak $(2,4 \%)$ tunaganda, 3 anak $(1,8 \%)$ gifted, dan 1 anak $(0,6 \%)$ didiagnosa tunawicara.

Pada penelitian ini dilakukan uji normalitas untuk melihat apakah distribusi sebaran data normal atau tidak. Uji normalitas pada penelitian ini berpedoman pada Central Limit Theorem (CLT). Pada CLT, asumsi normalitas dapat diabaikan jika jumlah responden penelitian lebih dari 30 (Spiegel \& Stephens, 2007). Selanjutnya dilakukan uji linearitas kedua variabel dikatakan linear apabila nilai
Hubungan Persepsi Dukungan Sosial dan Resiliensi Orang Tua Anak Berkebutuhan Khusus

Tabel 1. Uji Linearitas

\begin{tabular}{cccc}
\hline Variabel & Sig $(\boldsymbol{p}$-value $)$ & Taraf Signifikansi & Interpretasi \\
\hline $\begin{array}{c}\text { Resiliensi dan Persepsi } \\
\text { Dukungan Sosial }\end{array}$ & 0,00 & 0,05 & Linear \\
\hline
\end{tabular}

Berdasarkan tabel 2. dapat dilihat hasil uji korelasi pearson product moment diketahui bahwa nilai $\mathrm{p} 0,000$, hal ini menunjukkan bahwa skor korelasi berada dibawah taraf signifikansi $(\alpha$ $=0,05)$ maka, dapat dikatakan bahwa terdapat hubungan positif yang signifikan antara persepsi dukungan sosial dan resiliesi. Dari penelitian ini signifikansi lebih rendah dibandingkan taraf signifikansi $(\alpha=0,05)$.

Berdasarkan tabel 1, diketahui bahwa nilai probabilitas resiliensi dan persepsi dukungan sosial lebih rendah dibandingkan dengan taraf signifikansi. Maka dapat dikatakan bahwa resiliensi dan persepsi dukungan sosial memiliki hubungan yang linear. Selanjutnya, peneliti melakukan uji korelasi untuk mengetahui hubungan antara persepsi dukungan sosial dan resiliensi orang tua anak berkebutuhan khusus.

Tabel 2. Uji Korelasi

\begin{tabular}{ccccc}
\hline Variabel & $\boldsymbol{R}$ & $\boldsymbol{P}$ & $\begin{array}{c}\text { Taraf } \\
\text { Signifikansi }\end{array}$ & Interpretasi \\
\hline $\begin{array}{c}\text { Resiliensi dan Persepsi } \\
\text { dukungan sosial }\end{array}$ & 0,479 & 0,000 & 0,05 & Berkorelasi \\
\hline
\end{tabular}

Ketika individu memiliki persepsi dukungan sosial yang tinggi, individu akan memiliki persepsi yang baik atas sebuah dukungan. Jika ia memiliki persepsi yang baik, ia akan memiliki kepercayaan bahwa terdapat dukungan yang ia butuhkan ketika dihadapkan pada situasi sulit dan ia mampu menghadapinya. Apabila individu mampu menghadapi dan diketahui bahwa arah hubungan antar variabel adalah positif sehingga dapat diartikan apabila persepsi individu terhadap sebuah dukungan sosial tinggi, maka resiliensi individu pun akan mengalami peningkatan. 
Mauna

Rahmadianty Gazadinda

Novaria Rahma

diri, dapat beradaptasi dengan perubahan, dan optimisme. Kemudian dari tabel 2. diperoleh nilai koefisien korelasi (r) sebesar 0,479. Nilai koefisien korelasi (r) menyatakan bahwa hubungan persepsi dukungan sosial dan resiliensi tergolong sedang karena berada di rentang sekitar 0,5 (Cohen, 1988). Selain itu, untuk nilai koefiesien determinasi $\left(\mathrm{r}^{2}\right)$ sebesar 0,229 sehingga variabel persepsi dukungan sosial memberikan sumbangan sebesar 0,229 atau 22,9\% terhadap resiliensi.

Berdasarkan hasil analisis dapat diketahui bahwa hipotesis alternatif dalam penelitian ini diterima dan hipotesis nol ditolak. Nilai probabilitas kedua variabel adalah 0,000 . Hal tersebut menunjukkan bahwa terdapat hubungan yang signifikan antara persepsi dukungan sosial dan resiliensi pada orang tua anak berkebutuhan khusus.

\section{Kesimpulan}

Berdasarkan hasil penelitian dapat disimpulkan bahwa terdapat hubungan yang signifikan antara persepsi dukungan sosial dan resiliensi pada orang tua anak berkebutuhan khusus. Arah hubungan persepsi dukungan sosial dan resiliensi adalah positif, hal ini berarti apabila persepsi dukungan sosial individu tinggi maka semakin tinggi pula resiliensi.

\section{Daftar Pustaka}

Ahern. N.R. (2006). Adolescent resilience: An evolutionary concept analysis. Journal of Pediatric Nursing, 21(3), 175-185. DOI https://doi.org/10.1016/j.pedn.2005.07.00 9

Akbar, Z., Tahoma, O. (2018). Dukungan sosial dan resiliensi diri pada guru sekolah dasar. Jurnal Penelitian dan Pengukuran Psikologi, 7(1), 53-59. DOI: https://doi.org/10.21009/JPPP.071.07
Hubungan Persepsi Dukungan Sosial dan Resiliensi Orang Tua Anak Berkebutuhan Khusus

Andriani, A., dan Listiyandini, R. A. (2017). Peran kecerdasan sosial terhadap resiliensi pada mahasiswa tingkat awal. Psympathic: Jurnal Ilmiah Psikologi, 4(1), 67-90. DOI 10.15575/psy.v4i1.1261

Azmi, M. (2017). Resiliensi pada orang tua yang memiliki anak down syndrome (Studi Kasus Pada Orang Tua Siswa SLB Negeri Tanjung Selor di Wilayah Kalimantan Utara). PSIKOBORNEO, 5(2), 320-330. ejournal.psikologi.fisipunmul.ac.id

Azni, H. N. P., \& Nugraha, S. (2019). Hubungan social support dengan parenting stress pada ibu dengan anak tunagrahita di SLB-C Z Bandung. Prosiding Psikologi, 3(1), 153-157.

Bukhari, S. R., Afzal, F. (2017). Perceived social support predicts psychological problems among university students. The International Journal of Indian Psychology, 4(2), 18-27. DOI $\underline{18.01 .082 / 20170402}$

Carter, I., Park, W., Cragg, S. (2015). Perceptions of social support among canadian-born and non-canadian- born parents of children with developmental disabilities. Professional Development: The International Journal of Continuing Social Work Education, 18(1), 56-73. Retrieved From https://scholar.uwindsor.ca/socialworkpub /113/

Cohen, J. (1988). Statistical Power Analysis for the Behavioral Sciences (2nd ed.). Hillsdale, NJ: Lawrence Erlbaum Associates, Publishers.

Jurnal Penelitian dan Pengukuran Psikologi, Vol. 9, 2, Oktober 2020 
Mauna

Rahmadianty Gazadinda

Novaria Rahma

Cohen, S., \& Wills, T.A. (1985). Stress, social support, and the buffering hypothesis. Psychological bulletin, 98 (2), 310. DOI: 10.1037/0033-2909.98.2.310

Connor, K. M., Davidson, J. R. (2003). Development of a new resilience scale: the connor-davidson resilience scale (CD-RISC). Depression and Anxiety, 18, 76-82. DOI 10.1002/da.10113

Dag, I., Sen, G. (2018). The mediating role of perceived social support in the relationships between general causality orientations and locus of control with psychopathological symptoms. Europe's Journal of Psychology, 14(3), 531-553. DOI: 10.5964/ejop.v14i3.1563

Desiningrum, D. R. (2016). Psikologi Anak Berkebutuhan Khusus. Yogyakarta: Psikosain.

Eagle, D. E., Hybels, C. F., Proeschold-Bell, R. J. (2019). Perceived social support, received social support, and depression among clergy. Journal of Social and Personal Relationships, 36(7), 2055-2073. DOIhttps://doi.org/10.1177/02654075187 76134

Greeff, A. P., Nolting, C. (2013). Resilience in families of children with developmental disabilities. Families, Systems, dan Health, 31(4), 396-405. DOI: $10.1037 / \mathrm{a} 0035059$

Grotberg, E. H. (2003). Resilience for today: Gaining strength from adversity. Greenwood Publishing Group.

Kalkan, M., Epli-Koc, H. (2011). Perceived social support from friends as determinant of loneliness in a sample of primary
Hubungan Persepsi Dukungan Sosial dan Resiliensi Orang Tua Anak Berkebutuhan Khusus

school. US-China Education Review, 8(4), 547-551. ISSN 1548-6613

Kang, H. W., Park, M., Wallace, J. P. (2016). The impact of perceived social support, loneliness, and physical activity on quality of life in South Korean older adults. Journal of sport and health science, 7(2), 237-244.

Karaman, E., Efilti, E. (2019). Investigation of social support perception and self- esteem as predictors of psychological resilience of parents who have children with special educational needs. Asian Journal of Education and Training, 5(1), 112-120. DOI: 10.20448/journal.522.2019.51.112.1 $\underline{20}$

Khan, M. A., Kamran., \& R., Ashraf, S. (2017). Resilience, perceived social support and locus of control in mothers of children with autism vs those having normal children. Pakistan Journal of Professional Psychology: Research and Practice Vol, 8(1), 1-13.

Kondalkar, V.G. (2009). Organization Development. New Delhi: New Age International.

Marni, A., \& Yuniawati, R. (2015). Hubungan antara dukungan sosial dengan penerimaan diri pada lansia di Panti Wredha Budhi Dharma Yogyakarta. Empathy, 3(1), 1-7.

Muir, K., Strnadova, I. (2014). Whose responsibility? resilience in families of children with developmental disabilities. Disability dan Society, 29(6), 922937.

DOI https://doi.org/10.1080/09687599.2014.88 $\underline{6555}$

Jurnal Penelitian dan Pengukuran Psikologi, Vol. 9, 2, Oktober 2020 
Mauna

Rahmadianty Gazadinda

Novaria Rahma

Ong, H. L., Vaingankar, J. A., Abdin, E., Sambasivam, R., Fauziana, R., Tan, M. E., Chong, S. E., Goveas, R. R., Chiam, P. C., Subramaniam, M. (2018). Resilience and burden in caregivers of older adults: moderating and mediating effects of perceived social support. BMC psychiatry, 18, 1-9. DOI. 10.1186/s12888-018-1616$\mathrm{Z}$.

Pejicic, M., Ristic, M., Andelkovic, V. (2017). The mediating effect of cognitive emotion regulation strategies in the relationship between perceived social support and resilience in postwar youth. Journal of Community Psychology, 46(4), 457472.DOI

https://doi.org/10.1002/jcop.21951

Putri, A. M., Pramesti, W., Hapsari, R. D. (2019). Stres pada orang tua yang memiliki anak dengan gangguan spektrum autisme. Jurnal Psikologi Malahayati, 1(1),

7-13.

DOI: https://doi.org/10.33024/jpm.v1i1.1 $\underline{408}$

Rahayu, E. W. (2019). Resiliensi pada keluarga yang mempunyai anak disabilitas. PSIKOVIDYA, 23(1), 22-45.

Rahmawati, B. D., Listiyandini, R. A., Rahmatika, R. (2019). Seberapa jauh aku bisa bangkit? sebuah studi mengenai profil resiliensi psikologis remaja panti asuhan. Jurnal Pemikiran dan Penelitian Psikologi, 15(2), 232-248. DOI: 10.32528/ins.v15i2.1884

Raisa, R., Ediati, A. (2017). Hubungan antara dukungan sosial dengan resiliensi pada narapidana di lembaga pemasyarakatan kelas iia wanita semarang. Jurnal Empati, 5(3), 537-542.
Hubungan Persepsi Dukungan Sosial dan Resiliensi Orang Tua Anak Berkebutuhan Khusus

Sangadji, E. M., Sopiah. (2010). Metodologi Penelitian: Pendekatan Praktis dalam Penelitian. Yogyakarta: Penerbit Andi.

Sarafino, E. P., \& Smith, T. W. (2014). Health Psychology: Biopsychosocial Interactions. John Wiley \& Sons.

Spiegel, M. R., \& Stephens, L. J. (2007). Statistik Edisi Ketiga. Jakarta : Erlangga.

Sumekar, G. (2009). Anak berkebutuhan khusus : Cara membantu mereka agar berhasil dalam pendidikan inklusif. Universitas Negeri Padang Press (UNP Press).

Taylor, S. E., Sherman, D. K., Kim, H. S., Jarcho, J., Takagi, K., \& Dunagan, M. S. (2004). Culture and social support: Who seeks it and why?. Journal of personality and social psychology, 87(3), 354-362. DOI $\quad$ https://doi.org/10.1037/0022$\underline{3514.87 .3 .354}$

Uchino, B. (2004). Social support and physical health: understanding the health consequences of relationships. New Haven, CT: Yale University Press.

Webster, R I., Majnemer, A., Platt, R W., \& Shevell, MI. (2008). Child health and parental stress in school-age children with a preschool diagnosis of developmental delay. Journal of Child Neurology, 23(1), 32-38.DOI https://doi.org/10.1177/088307380730797 $\underline{7}$

Zimet, G. D., Dahlem, N. W., Zimet, S. G., Farley, G. K. (1988). The multidimensional scale of perceived social support. Journal of personality assessment, 52(1), 30-41

Jurnal Penelitian dan Pengukuran Psikologi, Vol. 9 , 2 , Oktober 2020 